\title{
Reinfection Rate and Its Associated Factors after Two-Stage Revision for Infected Total Knee Arthroplasty
}

Chang Hyun Nam

Joint \& Arthritis Research, Himchan Hospital

Su Chan Lee

Joint \& Arthritis Research, Himchan Hospital

Kyungwon Choi

Joint \& Arthritis Research, Himchan Hospital

Ji-Hoon Baek ( $\sim$ himchanhospital@gmail.com )

Joint \& Arthritis Research, Himchan Hospital

Hye Sun Ahn

Joint\& Arthritis Research, Himchan Hospital

Research article

Keywords: Two-stage revision, Infected total knee arthroplasty, Recurrence of infection

Posted Date: January 29th, 2021

DOI: https://doi.org/10.21203/rs.3.rs-157720/v1

License: (c) (7) This work is licensed under a Creative Commons Attribution 4.0 International License. Read Full License 


\section{Abstract}

Background: Two-stage revision is the gold standard for treatment of infected total knee arthroplasty. The purpose of our study was to evaluate the reinfection rate of two-stage revision and to analyze the factors affecting the prognosis of two-stage revision for infected total knee arthroplasty.

Methods: One hundred seven cases of two-stage revision for infected total knee arthroplasty were reviewed retrospectively from March 2006 to November 2019. We evaluated possible risk factors between success and reinfection groups. Statistical analyses included multivariable logistic regression analysis to examine the relative contribution of risk factors to the success of two-stage revision.

Results: There were 19 cases of reinfection (17.8\%) after two-stage revision in our center. Between the success and reinfection groups, there was a significant difference in history of cancer $(p=0.015)$. Also, multivariable logistic regression analysis of risk factors demonstrated history of cancer $(H R 5.928, p=0.015)$. There were no statistically significant differences in reinfection relative to other risk factors.

Conclusions: In subjects undergoing two-stage revision for infected total knee arthroplasty, history of cancer was a risk factor for reinfection, though no other significant differences between risk factors was shown for reinfection.

Trial registration: Retrospectively registered

\section{Level of evidence: IV}

\section{Background}

Infected total knee arthroplasty (TKA) is the most serious complication of the surgical procedure, and prognosis varies greatly depending on treatment method [1]. This devastating complication is associated with considerable morbidity [2,3] and economic burden [4]. The incidence of infection following primary TKA ranges from 1-2\% [5]. There are various treatment options, including chronic antibiotic suppression [6, 7]; irrigation and debridement (I \& D) with component retention [8-13]; one-stage revision [14, 15]; two-stage revision [10, 16-18]; and salvage procedures such as resection arthroplasty, arthrodesis, or amputation [19-23]. Of these treatment options, two-stage revision is considered the gold standard, with a high rate of infection control ranging from $72-100 \%$ [24, 25]. However, recurrence of reinfection after two-stage revision occurs in up to $19 \%$ of cases [26-28], which elucidates the socioeconomic and individual burden of infected TKA. Previous studies have attempted to identify risk factors associated with reinfection after two-stage revision [29-33]. However, there were no common risk factors among studies. The purpose of the present study was to evaluate the reinfection rate of two-stage revision and to analyze the factors affecting prognosis of two-stage revision for infected TKA.

\section{Methods}

The design of this retrospective study was approved by the institutional review board (IRB) at the author's hospital, and all patients provided informed consent.

One hundred forty-two cases (136 patients) of infected TKA from 2008 to 2019 at a single center were reviewed retrospectively. Among these, 35 cases were successfully treated without need for component removal or antibiotic-loaded cement spacer insertion, and four failure cases required two-stage revision after infection control. Therefore, a total of 107 cases (104 patients) of two-stage revision for infected TKA was analyzed including four failure cases (Fig. 1).

The following patient demographics were recorded: age, sex, body mass index (BMI), comorbidities (hypertension, diabetes mellitus (DM), heart disease), previous knee surgery, history of cancer, alcohol drinking, smoking, infection interval, laboratory tests (hemoglobin (Hb), white blood cell (WBC), erythrocyte sedimentation rate (ESR), C-reactive protein (CRP)), operation tourniquet time, and type of microorganism.

The types of organisms were 1) methicillin-resistant staphylococci aureus (MRSA); 2) "difficult to treat" (DTT) organisms including quinolone-resistant gramnegative bacteria, rifampicin-resistant Staphylococcus, Enterococcus, and Candida; and 3) all other organism summarized as "easy to treat" (ETT) including anaerobic bacteria, gram-negative bacteria, culture-negative infection, coagulase-negative Staphylococcus, polymicrobial infection, staphylococci aureus, and streptococci $[34,35]$.

The diagnosis of periprosthetic joint infection prior to two-stage revision was confirmed when at least three of the following criteria were met: 1 ) CRP $>1$ $\mathrm{mg} / \mathrm{dl}$; 2) ESR > $30 \mathrm{~mm} / \mathrm{h}$; 3) positive culture from joint aspirate; 4) pus at operation; and 5) positive intra-operative culture [36].

Two-stage revision consisted of removal of all prosthetic components, insertion of a vancomycin-impregnated cement ( $2 \mathrm{~g}$ vancomycin per $40 \mathrm{~g}$ cement) articulating spacer, and delayed reimplantation. After the first stage, patients underwent physiotherapy to encourage passive knee movement and preserve quadriceps strength. Delayed reimplantation was performed when the wound was healthy and the patient was clinically stable with normal CRP. Clinical and radiological data from all patients who underwent joint replacement were collected retrospectively from the joint registries of our institutions. Patients had been examined before surgery and at six weeks, six months, and one year after surgery and yearly thereafter.

Reinfection was diagnosed by clinical signs, blood work (ESR and CRP), and positive culture of synovial aspiration. The mean follow-up period after revision TKA was $62.2 \pm 36.9$ months. In the reinfection group, 16 patients were females, three patients were male, and the mean age was $70.7 \pm 7.8$ years. The mean time from revision TKA to diagnosis of reinfection was $15.0 \pm 18.8$ months. We evaluated possible risk factors between success and reinfection groups.

Differences in continuous variables between the two groups were evaluated using the unpaired t-test or Mann-Whitney rank test. The data are shown as mean \pm standard deviation. For discrete variables, differences are shown as count and percentage and analyzed with the $x 2$ outcome (= reinfection) occurred over 15 
years of follow-up. Multivariate logistic regression analysis was used to assess the independent impact factor for reinfection. A two-tailed $p$-value $<0.05$ was considered statistically significant.

\section{Results}

There were 19 cases of reinfection (17.8\%) after two-stage revision in our center. Three patients were treated by I \& D, and seven patients underwent a twostage re-revision TKA. Seven patients who were in poor physical condition or refused additional surgical procedures were treated with antimicrobial therapy, and two cases were lost to follow-up.

The demographic characteristics and univariate analysis of infected TKA patients are shown in Table 1. The mean durations from primary TKA to infection and from infection to implant removal in all patients were $34.3 \pm 42.3$ months and $20.7 \pm 44.5$ weeks, respectively. 
Table 1

Demographic characteristics of infected total knee arthroplasty patients

\begin{tabular}{|c|c|c|c|c|}
\hline Variable & $\begin{array}{l}\text { All patients } \\
(n=107)\end{array}$ & Reinfection group $(n=19)$ & Non-reinfection group $(n=88)$ & $p$-value \\
\hline Age at revision TKA (years)* & $70.6 \pm 6.7$ & $70.7 \pm 7.8$ & $70.5 \pm 6.5$ & 0.935 \\
\hline Sext & & & & $>0.999$ \\
\hline Male & $19(17.8)$ & $3(15.8)$ & $16(18.2)$ & \\
\hline Female & $88(82.2)$ & $16(84.2)$ & $72(81.8)$ & \\
\hline $\operatorname{BMI}\left(\mathrm{kg} / \mathrm{m}^{2}\right) \star$ & $25.6 \pm 3.5$ & $25.4 \pm 3.6$ & $25.7 \pm 3.4$ & 0.804 \\
\hline Hypertensiont & $73(68.2)$ & $15(78.9)$ & $58(65.9)$ & 0.268 \\
\hline Diabetes mellitust & $29(27.1)$ & $6(31.6)$ & $23(26.1)$ & 0.628 \\
\hline Heart diseaset & $3(2.8)$ & $1(5.3)$ & $2(2.3)$ & 0.447 \\
\hline Previous knee surgery† & $15(14.0)$ & $2(10.5)$ & $13(14.8)$ & $>0.999$ \\
\hline Cancert & $10(9.3)$ & $5(26.3)$ & $5(5.7)$ & 0.015 \\
\hline Alcohol drinkingt & $2(1.9)$ & $0(0)$ & $2(2.3)$ & $>0.999$ \\
\hline Smokingt & $5(4.7)$ & $0(0)$ & $5(5.7)$ & 0.583 \\
\hline Time from primary TKA to infection $(m)^{*}$ & $34.3 \pm 42.3$ & $39.3 \pm 46.7$ & $33.2 \pm 41.5$ & 0.541 \\
\hline Time from infection to implant removal $(w)^{*}$ & $20.7 \pm 44.5$ & $41.7 \pm 47.0$ & $23.0 \pm 48.3$ & 0.330 \\
\hline Time from implant removal to revision TKA $(w)^{*}$ & $6.2 \pm 2.4$ & $6.9 \pm 2.5$ & $6.1 \pm 2.4$ & 0.197 \\
\hline Time from revision TKA to reinfection $(\mathrm{m})^{\star}$ & . & $15.0 \pm 18.8$ & . & . \\
\hline Time from revision TKA to latest follow-up $(\mathrm{m})^{\star}$ & $61.2 \pm 39.1$ & $62.2 \pm 36.9$ & $61.0 \pm 39.7$ & 0.900 \\
\hline Preoperative primary TKA, CRP* & $0.2 \pm 0.5$ & $0.25 \pm 0.34$ & $0.23 \pm 0.58$ & 0.945 \\
\hline Preoperative primary TKA, WBC* & $7.6 \pm 2.4$ & $7.9 \pm 2.4$ & $7.6 \pm 2.4$ & 0.684 \\
\hline Preoperative primary TKA, $\mathrm{Hb}^{\star}$ & $13.3 \pm 1.3$ & $13.0 \pm 1.6$ & $13.4 \pm 1.2$ & 0.209 \\
\hline Preoperative primary TKA, ESR* & $22.5 \pm 18.8$ & $26.3 \pm 23.8$ & $21.5 \pm 17.4$ & 0.813 \\
\hline Infected TKA, CRP* & $8.5 \pm 9.2$ & $8.74 \pm 7.91$ & $8.45 \pm 9.54$ & 0.341 \\
\hline Infected TKA, WBC* & $9.8 \pm 3.6$ & $9.1 \pm 3.3$ & $9.9 \pm 3.7$ & 0.289 \\
\hline Infected TKA, Hb* & $11.7 \pm 1.5$ & $11.4 \pm 1.6$ & $11.8 \pm 1.5$ & 0.312 \\
\hline Infected TKA, ESR* & $69.8 \pm 30.9$ & $80.3 \pm 29.8$ & $67.1 \pm 30.8$ & 0.921 \\
\hline Revision TKA, tourniquet time $(\mathrm{m})^{*}$ & $90.0 \pm 23.3$ & $88.9 \pm 17.4$ & $90.3 \pm 24.4$ & 0.851 \\
\hline Type of microorganism & & & & 0.630 \\
\hline MRSA & $4(3.7)$ & $1(5.3)$ & $3(3.4)$ & \\
\hline DTT & $13(12.1)$ & $3(15.8)$ & $10(11.4)$ & \\
\hline ETT & $90(84.1)$ & $15(78.9)$ & $75(85.2)$ & \\
\hline \multicolumn{5}{|c|}{ * The values are given as mean and standard deviation. } \\
\hline \multicolumn{5}{|c|}{ † The values are given as number with percentage in parentheses. } \\
\hline $\begin{array}{l}\text { bbreviations: TKA, total knee arthroplasty; BMI, } \\
\text { edimentation rate; MRSA, methicillin-resistant st }\end{array}$ & index; CR & active protein; WBC, white & cell; Hb, hemoglobin; ESR, ery & \\
\hline
\end{tabular}

The mean time from revision to reinfection in the reinfection group was $15.0 \pm 18.8$ months. Between the reinfection and success groups, age, sex, and BMI were similar, and there were no significant differences in hypertension, DM, heart disease, previous knee surgery, alcohol drinking, smoking, time from TKA to infection, time from infection to implant removal, time from implant removal to revision interval, time from revision to latest follow up, preoperative primary TKA lab values (CRP, WBC, Hb, and ESR), infected TKA lab values (CRP, WBC, Hb, and ESR), revision TKA tourniquet time, and type of microorganism (MRSA, DTT, and ETT). The only significant difference was history of cancer $(p=0.015)$, which remained significant in multivariable logistic regression analysis (HR $5.928, p=0.015$ ) (Table 2). There were no statistically significant differences in reinfection relative to other risk factors. 
Table 2

Multivariable logistic regression analysis of the relative contribution of each variable to reinfection after two-stage revision total knee

\begin{tabular}{|c|c|c|c|}
\hline Variable & Hazard ratio & $95 \%$ Confidence interval & $p$-value \\
\hline Age at revision TKA (years)* & 0.981 & $0.911-1.055$ & 0.608 \\
\hline Sex, male & 0.843 & $0.219-3.244$ & $>0.999$ \\
\hline $\mathrm{BMI}\left(\mathrm{kg} / \mathrm{m}^{2}\right)$ & 0.976 & $0.842-1.131$ & 0.749 \\
\hline Hypertension & 1.939 & $0.591-6.361$ & 0.268 \\
\hline Diabetes mellitus & 1.304 & $0.443-3.832$ & 0.628 \\
\hline Heart disease & 2.388 & $0.205-27.780$ & 0.447 \\
\hline Previous knee surgery & 0.678 & $0.139-3.292$ & $>0.999$ \\
\hline Cancer & 5.928 & $1.517-23.160$ & 0.015 \\
\hline Alcohol drinking & 0.819 & $0.748-0.896$ & $>0.999$ \\
\hline Smoking & 0.813 & $0.741-0.892$ & 0.583 \\
\hline Time from primary TKA to infection (m) & 1.003 & $0.992-1.014$ & 0.567 \\
\hline Time from infection to implant removal (w) & 0.987 & $0.965-1.010$ & 0.289 \\
\hline Time from implant removal to revision TKA (w) & 1.122 & $0.936-1.345$ & 0.210 \\
\hline Preoperative primary TKA, CRP & 0.770 & $0.171-3.465$ & 0.734 \\
\hline Preoperative primary TKA, WBC & 1.037 & $0.827-1.302$ & 0.748 \\
\hline Preoperative primary $\mathrm{TKA}, \mathrm{Hb}$ & 0.728 & $0.472-1.122$ & 0.151 \\
\hline Preoperative primary TKA, ESR & 0.994 & $0.957-1.032$ & 0.764 \\
\hline Infected TKA, CRP & 1.003 & $0.951-1.058$ & 0.902 \\
\hline Infected TKA, WBC & 0.920 & $0.783-1.080$ & 0.310 \\
\hline Infected TKA, Hb & 0.817 & $0.578-1.156$ & 0.255 \\
\hline Infected TKA, ESR & 1.001 & $0.984-1.018$ & 0.866 \\
\hline Revision TKA, tourniquet time (m) & 0.997 & $0.976-1.019$ & 0.820 \\
\hline
\end{tabular}

In 19 reinfection cases, those with cancer had a final collection period of 3 to 99 months, and those without had a final collection period of 0 to 157 months. There were a total of 10 cancer patients: five were reinfected and five were observed without reinfection. In the reinfection-cancer group, there were two uterine cancers, two gastric cancers, and one colorectal cancer (Table 3). 
Table 3

Summary of reinfection after two-stage revision total knee arthroplasty cases

\begin{tabular}{|c|c|c|c|c|c|c|c|c|c|c|c|}
\hline $\begin{array}{l}\text { Patient } \\
\text { No. }\end{array}$ & $\begin{array}{l}\text { Age at } \\
\text { revision } \\
\text { TKA } \\
\text { /sex }\end{array}$ & $\begin{array}{l}\text { BMI } \\
\left(\mathrm{kg} / \mathrm{m}^{2}\right)\end{array}$ & $\begin{array}{l}\text { HT/DM/ } \\
\text { others }\end{array}$ & Cancer & $\begin{array}{l}\text { Time } \\
\text { from } \\
\text { primary } \\
\text { TKA to } \\
\text { infection } \\
\text { (m) }\end{array}$ & $\begin{array}{l}\text { Time } \\
\text { from } \\
\text { infection } \\
\text { to } \\
\text { implant } \\
\text { removal } \\
\text { (w) }\end{array}$ & $\begin{array}{l}\text { Time } \\
\text { from } \\
\text { implant } \\
\text { removal } \\
\text { to } \\
\text { revision } \\
\text { TKA (w) }\end{array}$ & $\begin{array}{l}\text { Time from } \\
\text { revision } \\
\text { TKA to } \\
\text { reinfection } \\
\text { (m) }\end{array}$ & $\begin{array}{l}\text { Time } \\
\text { from } \\
\text { revision } \\
\text { TKA to } \\
\text { latest } \\
\text { follow- } \\
\text { up (m) }\end{array}$ & $\begin{array}{l}\text { Type of } \\
\text { microorganism } \\
\text { at infection }\end{array}$ & $\begin{array}{l}\text { Type c } \\
\text { microi } \\
\text { at rein }\end{array}$ \\
\hline 1 & $61 / F$ & 24.5 & $\begin{array}{l}\text { Yes/Yes/ } \\
\text { No }\end{array}$ & $\begin{array}{l}\text { Uterine } \\
\text { cancer } \\
(\mathrm{TAH})\end{array}$ & 12 & 1 & 7 & 0 & 91 & No growth & Hafnic \\
\hline 2 & $71 / \mathrm{M}$ & 19.5 & $\begin{array}{l}\text { Yes/No/ } \\
\text { Tuberculosis }\end{array}$ & No & 11 & 1 & 9 & 2 & 122 & $\begin{array}{l}\text { Staphylococcus } \\
\text { aureus }\end{array}$ & No gre \\
\hline 3 & $69 / \mathrm{F}$ & 26.1 & $\begin{array}{l}\text { Yes/Yes/ } \\
\text { Angina }\end{array}$ & $\begin{array}{l}\text { Gastric } \\
\text { cancer } \\
\text { (subtotal } \\
\text { gastrectomy) }\end{array}$ & 27 & 5 & 8 & 1 & 10 & $\begin{array}{l}\text { Staphylococcus } \\
\text { aureus }\end{array}$ & No grc \\
\hline 4 & $64 / F$ & 26.6 & $\begin{array}{l}\text { Yes/No/ } \\
\text { Tuberculosis }\end{array}$ & No & 9 & 12 & 11 & 41 & 123 & $\begin{array}{l}\text { Coagulase } \\
\text { negative } \\
\text { Staphylococcus }\end{array}$ & No grc \\
\hline 5 & $74 / \mathrm{F}$ & 24.1 & $\begin{array}{l}\text { Yes/Yes/ } \\
\text { No }\end{array}$ & No & 22 & 8 & 7 & 34 & 88 & No growth & No grc \\
\hline 6 & $73 / \mathrm{M}$ & 26.9 & $\begin{array}{l}\text { Yes/Yes/ } \\
\text { No }\end{array}$ & $\begin{array}{l}\text { Colorectal } \\
\text { cancer } \\
\text { (cured) }\end{array}$ & 3 & 2 & 5 & 43 & 99 & $\begin{array}{l}\text { streptococcus } \\
\text { pyogenes }\end{array}$ & No grc \\
\hline 7 & $61 / F$ & 27.6 & $\begin{array}{l}\text { No/No/ } \\
\text { No }\end{array}$ & No & 3 & 52 & 4 & 0 & 93 & No growth & No grc \\
\hline 8 & $73 / \mathrm{F}$ & 25.4 & $\begin{array}{l}\text { No/No/ } \\
\text { No }\end{array}$ & No & 3 & 40 & 4 & 61 & 91 & No growth & No grc \\
\hline 9 & $75 / F$ & 28.8 & $\begin{array}{l}\text { No/No/ } \\
\text { No }\end{array}$ & No & 29 & 1 & 4 & 13 & 76 & No growth & $\begin{array}{l}\text { Esche } \\
\text { coli }\end{array}$ \\
\hline 10 & $73 / \mathrm{F}$ & 18.3 & $\begin{array}{l}\text { Yes/Yes/ } \\
\text { Cerebrovascular } \\
\text { accident }\end{array}$ & No & 60 & 2 & 6 & 22 & 39 & Escherichia coli & No grc \\
\hline 11 & $68 / F$ & 29.6 & $\begin{array}{l}\text { Yes/Yes/ } \\
\text { No }\end{array}$ & No & 1 & 2 & 10 & 3 & 63 & No growth & No grc \\
\hline 12 & $66 / F$ & 23.4 & $\begin{array}{l}\text { Yes/No/ } \\
\text { No }\end{array}$ & No & 137 & 39 & 4 & 0 & 36 & No growth & No gre \\
\hline 13 & $53 / \mathrm{F}$ & 24.6 & $\begin{array}{l}\text { No/Yes/ } \\
\text { No }\end{array}$ & No & 34 & 13 & 7 & 37 & 42 & $\begin{array}{l}\text { Staphylococcus } \\
\text { aureus }\end{array}$ & No grc \\
\hline 14 & $73 / F$ & 27.9 & $\begin{array}{l}\text { Yes/Yes/ } \\
\text { No }\end{array}$ & No & 24 & 0 & 5 & 0 & 67 & $\begin{array}{l}\text { Achromobacter } \\
\text { xylosoxidans } \\
\text { subsp } \\
\text { xylosoxidans }\end{array}$ & No grc \\
\hline 15 & $63 / F$ & 22.2 & $\begin{array}{l}\text { Yes/Yes/ } \\
\text { Cardiac } \\
\text { insufficiency }\end{array}$ & No & 141 & 1 & 11 & 5 & 65 & No growth & No grc \\
\hline 16 & $52 / \mathrm{F}$ & 32.0 & $\begin{array}{l}\text { Yes/Yes/ } \\
\text { No }\end{array}$ & No & 3 & 5 & 6 & 9 & 40 & $\begin{array}{l}\text { Candida } \\
\text { albicans }\end{array}$ & No grc \\
\hline
\end{tabular}




\begin{tabular}{|c|c|c|c|c|c|c|c|c|c|c|c|}
\hline $\begin{array}{l}\text { Patient } \\
\text { No. }\end{array}$ & $\begin{array}{l}\text { Age at } \\
\text { revision } \\
\text { TKA } \\
\text { /sex }\end{array}$ & $\begin{array}{l}\text { BMI } \\
\left(\mathrm{kg} / \mathrm{m}^{2}\right)\end{array}$ & $\begin{array}{l}\text { HT/DM/ } \\
\text { others }\end{array}$ & Cancer & $\begin{array}{l}\text { Time } \\
\text { from } \\
\text { primary } \\
\text { TKA to } \\
\text { infection } \\
\text { (m) }\end{array}$ & $\begin{array}{l}\text { Time } \\
\text { from } \\
\text { infection } \\
\text { to } \\
\text { implant } \\
\text { removal } \\
\text { (w) }\end{array}$ & $\begin{array}{l}\text { Time } \\
\text { from } \\
\text { implant } \\
\text { removal } \\
\text { to } \\
\text { revision } \\
\text { TKA (w) }\end{array}$ & $\begin{array}{l}\text { Time from } \\
\text { revision } \\
\text { TKA to } \\
\text { reinfection } \\
\text { (m) }\end{array}$ & $\begin{array}{l}\text { Time } \\
\text { from } \\
\text { revision } \\
\text { TKA to } \\
\text { latest } \\
\text { follow- } \\
\text { up (m) }\end{array}$ & $\begin{array}{l}\text { Type of } \\
\text { microorganism } \\
\text { at infection }\end{array}$ & $\begin{array}{l}\text { Type c } \\
\text { microi } \\
\text { at rein }\end{array}$ \\
\hline 17 & $71 / F$ & 27.4 & $\begin{array}{l}\text { Yes/No/ } \\
\text { No }\end{array}$ & $\begin{array}{l}\text { Uterine } \\
\text { cancer } \\
\text { (cured) }\end{array}$ & 32 & 1 & 5 & 8 & 12 & No growth & $\begin{array}{l}\text { Strept } \\
\text { dysga } \\
\text { ssp ec }\end{array}$ \\
\hline 18 & $69 / \mathrm{M}$ & 19.8 & $\begin{array}{l}\text { Yes/No/ } \\
\text { No }\end{array}$ & $\begin{array}{l}\text { Gastric } \\
\text { cancer } \\
\text { (subtotal } \\
\text { gastrectomy) }\end{array}$ & 129 & 9 & 11 & 6 & 18 & No growth & No grc \\
\hline 19 & $68 / F$ & 27.9 & $\begin{array}{l}\text { Yes/No/ } \\
\text { No }\end{array}$ & No & 66 & 2 & 7 & 1 & 7 & No growth & No grc \\
\hline
\end{tabular}

Abbreviations: TKA, total knee arthroplasty; BMI, body mass index; $\mathrm{HT}$, hypertension; DM, diabetes mellitus; $\mathrm{F}$, female; $\mathrm{M}$, male; TAH, total abdominal hysterect debridement; $f / u$, follow-up

Figure 2 depicts the cumulative survival rates between the cancer and non-cancer groups during a one-year period. There was a significantly higher chance that subjects in the cancer group were reinfected within one year compared to that in subjects in the non-cancer group $(33.3 \%$ vs. $7.2 \%, p=0.002)$.

\section{Discussion}

Infection remains one of the most serious complications of TKA. Two-stage revision is the standard treatment of infected TKA and seems to eradicate infection and provide a functional outcome.

This case-control study aimed to evaluate the reinfection rate of two-stage revision and to analyze the factors affecting prognosis of two-stage revision for infected TKA. The most important finding of our study is that history of cancer was the only risk factor for reinfection after two-stage revision for infected TKA. There was a significantly higher chance that a subject with cancer would be reinfected within one year than a subject without. In our study, there were 19 cases of reinfection (17.8\%) after two-stage revision. This is similar to previous studies that showed a $10-12 \%$ incidence of reinfection after two-stage revision $[31,37,38]$.

Several studies have reported risk factors and reinfection rate of two-stage revision for infected TKA [26, 33, 39-41]. Sabry et al. reported the following as preoperative predictors of failure following two-stage revision: duration of symptoms, time from index surgery, number of previous surgeries, high markers of inflammation levels (CRP, ESR, and peripheral WBC count), lower hemoglobin and hematocrit, need for soft tissue coverage, time to reimplantation, previous infection in the same joint, higher the American society of anesthesiologists (ASA) score, DM, anemia, heart disease, and infection with a gram-negative organism in the absence of malignancy [39]. Kubista et al. reported chronic lymphedema, revision between resection and definitive reimplantation, and intravenously administered cefazolin as the strongest positive predictors of treatment failure [33]. Fashingbauer et al. reported revision during or after a twostage exchange, number of surgeries, and alcohol abuse as risk factors for recurrence, and that recurrence rates did not differ among organisms [32].

Fehring et al reported repeat two-stage exchange arthroplasty for periprosthetic knee infection is dependent on host grade(Musculoskeletal Infection Society, MSIS) [40]. Also, Vadiee et al found a higher incidence of failure in those patients with poor general health based on MSIS score, inadequate soft tissue envelope and resistant bacteria [41].

Previous studies attempted to identify risk factors associated with reinfection after two-stage revision [29-33]. However, little information is available concerning the prognosis and risk factors in reinfection after two-stage revision for infected TKA. In this study, that undergoing revision operation for infected TKA with history of cancer (10 patients) showed a relatively high re-infection rate of $50 \%$ (5 patients).

This study had some limitations. First, it was retrospectively designed and may have introduced bias when data were not accurately reported in the medical chart. In particular, medical history was recorded through patient statements. Second, in the cancer group, we could not assess cancer recurrence or immunosuppressant use during the follow-up period. Third, we could not analyze antibiotics used due to individualization of treatment regimens without a standardized protocol. Fourth, the finding that there was no organism-dependent difference in reinfection after two-stage revision conflicts with the current literature [42-44]. One possible reason for this discrepancy is that our study had an insufficient number of cases to achieve adequate power analyses.

Nevertheless, our study says that history of cancer might be especially important among systemic host compromising factors and significantly higher chance that subjects in the cancer group were reinfected within one year compared to that in subjects in the non-cancer group.

\section{Conclusions}

In conclusion, patients with identified history of cancer undergoing revision operation for infected TKA showed worse outcomes. Therefore, staged revision arthroplasty in patients with history of cancer should be closely observed to minimize re-infection, and these patients should be informed of the high probability of infection. 


\section{Abbreviations}

TKA: total knee arthroplasty; I \& D: irrigation and debridement; IRB: institutional review board; BMI: body mass index; DM: diabetes mellitus; Hb: hemoglobin; WBC: white blood cell; ESR: erythrocyte sedimentation rate; ERP: C-reactive protein; MRSA: methicillin-resistant staphylococci aureus; DTT: difficult to treat; ETT: easy to treat; ASA: American society of anesthesiologists; MSIS: musculoskeletal infection society; HT: hypertension; F: female; M: male; TAH: total abdominal hysterectomy; f/u: follow-up

\section{Declarations}

Ethics approval and consent to participate: This study was approved by the Institutional Review Board of Himchan hospital. All patients provided written informed consent to use their medical records in advance.

Consent for publication: Authors agree to publication. This manuscript has not been published in any journal

Availability of data and material: All data generated or analysed during this study are included in this published article.

Competing interests: Each author certifies that he or she has no commercial association (eg. consultancies, stock ownership, equity interest, patent, licensing arrangements, etc.) that might pose a conflict of interest in connection with the submitted article.

Funding: Not applicable.

Authors' contributions: Chang Hyun Nam, Ji-Hoon Baek: writing and revision of article. Su Chan Lee, Kyungwon Choi, Hye Sun Ahn: data collection and statistical analysis.

Acknowledgements: This work was supported by our institution. Published with written consent of the patient.

\section{References}

1. Fehring TK, Odum S, Griffi n WL, Mason JB, Nadaud M. Early failures in total knee arthroplasty. Clin Orthop Relat Res. 2001;392:315-8.

2. Darouiche RO. Treatment of infections associated with surgical implants. N Engl J Med. 2004;350:1422-9.

3. Bozic KJ, Ries MD. The impact of infection after total hip arthroplasty on hospital and surgeon resource utilization. J Bone Joint Surg Am. 2005;87:174651.

4. Kurtz SM, Lau E, Schmier J, Ong KL, Zhao K, Parvizi J. Infection burden for hip and knee arthroplasty in the United States. J Arthroplasty. 2008 ;23:984-91.

5. Kurtz SM, Ong KL, Lau E, Bozic KJ, Berry D, Parvizi J. Prosthetic joint infection risk after TKA in the Medicare population. Clin Orthop Relat Res. 2010;468(1):52-6.

6. Garvin KL, Cordero GX. Infected total knee arthroplasty: diagnosis and treatment. Instr Course Lect. 2008;57:305-15.

7. Trebse R, Pisot V, Trampuz A. Treatment of infected retained implants. J Bone Joint Surg Br. 2005;87:249-56.

8. Deirmengian C, Greenbaum J, Lotke PA, Booth RE Jr, Lonner JH. Limited success with open debridement and retention of components in the treatment of acute Staphylococcus aureus infections after total knee arthroplasty. J Arthroplasty. 2003;18:22-6.

9. Hartman MB, Fehring TK, Jordan L, Norton HJ. Periprosthetic knee sepsis. The role of irrigation and debridement. Clin Orthop Relat Res. 1991;273:113-8.

10. Laffer RR, Graber P, Ochsner PE, Zimmerli W. Outcome of prosthetic knee-associated infection: evaluation of 40 consecutive episodes at a single centre. Clin Microbiol Infect. 2006;12:433-9.

11. Marculescu CE, Berbari EF, Hanssen AD, Steckelberg JM, Harmsen SW, Mandrekar JN, et al. Outcome of prosthetic joint infections treated with debridement and retention of components. Clin Infect Dis. 2006;42:471-8.

12. Mont MA, Waldman B, Banerjee C, Pacheco IH, Hungerford DS. Multiple irrigation, debridement, and retention of components in infected total knee arthroplasty. J Arthroplasty. 1997;12:426-33.

13. Schoifet SD, Morrey BF. Treatment of infection after total knee arthroplasty by debridement with retention of the components. J Bone Joint Surg Am. 1990;72:1383-90.

14. Hanssen AD, Rand JA. Evaluation and treatment of infection at the site of a total hip or knee arthroplasty. Instr Course Lect. 1999;48:111-22.

15. Silva M, Tharani R, Schmalzried TP. Results of direct exchange or debridement of the infected total knee arthroplasty. Clin Orthop Relat Res. 2002;404:125-31.

16. Durbhakula SM, Czajka J, Fuchs MD, Uhl RL. Antibiotic-loaded articulating cement spacer in the 2-stage exchange of infected total knee arthroplasty. J Arthroplasty. 2004;19:768-74.

17. Haddad FS, Masri BA, Campbell D, McGraw RW, Beauchamp CP, Duncan CP. The PROSTALAC functional spacer in two-stage revision for infected knee replacements. Prosthesis of antibioticloaded acrylic cement. J Bone Joint Surg Br. 2000;82:807-12.

18. Pitto RP, Castelli CC, Ferrari R, Munro J. Pre-formed articulating knee spacer in two-stage revision for the infected total knee arthroplasty. Int Orthop. 2005;29:305-8.

19. Ellingsen DE, Rand JA. Intramedullary arthrodesis of the knee after failed total knee arthroplasty. J Bone Joint Surg Am. 1994;76:870-7.

20. Falahee MH, Matthews LS, Kaufer H. Resection arthroplasty as a salvage procedure for a knee with infection after a total arthroplasty. J Bone Joint Surg Am. 1987;69:1013-21.

Page $8 / 10$ 
21. Isiklar ZU, Landon GC, Tullos HS. Amputation after failed total knee arthroplasty. Clin Orthop Relat Res. 1994;299:173-8.

22. Leone JM, Hanssen AD. Management of infection at the site of a total knee arthroplasty. J Bone Joint Surg Am. 2005;87:2335-48.

23. Wiedel JD. Salvage of infected total knee fusion: the last option. Clin Orthop Relat Res. 2002;404:139-42.

24. Lee JK, Choi CH. Two-stage reimplantation in infected total knee arthroplasty using a re-sterilized tibial polyethylene insert and femoral component. J Arthroplasty. 2012;27(9):1701-6.

25. Teeny SM, Dorr L, Murata G, Conaty P. Treatment of infected total knee arthroplasty: irrigation and debridement versus two-stage reimplantation. J Arthroplasty. 1990;5(1):35-9.

26. Cochran AR, Ong KL, Lau E, Mont MA, Malkani AL. Risk of reinfection after treatment of infected total knee arthroplasty. J Arthroplasty. 2016;31:156-61.

27. Yu Q, Luo M, Wu S, Lai A, Sun Y, Hu Q, et al. Comparison of infection eradication rate of using articulating spacers containing bio-inert materials versus all-cement articulating spacers in revision of infected TKA: a systematic review and meta-analysis. Arch Orthop Trauma Surg. 2019;139(5):695-707.

28. Akgun D, Muller M, Perka C, Winkler T. An often-unrecognized entity as cause of recurrent infection after successfully treated two-stage exchange arthroplasty: hematogenous infection. Arch Orthop Trauma Surg. 2018;138(9):1199-206.

29. Shrader MW, Schall D, Parvizi J, McCarthy JT, Lewallen DG. Total hip arthroplasty in patients with renal failure: a comparison between transplant and dialysis patients. J Arthroplasty. 2006;21(3):324-9.

30. Hanssen AD, Trousdale RT, Osmon DR. Patient outcome with reinfection following reimplantation for the infected total knee arthroplasty. Clin Orthop Relat Res. 1995;321:55-67.

31. Hanssen AD, Osmon DR. Evaluation of a staging system for infected hip arthroplasty. Clin Orthop Relat Res. 2002;403:16-22.

32. Faschingbauer M, Bieger R, Kappe R, Weiner C, Freitag T, Reichel H. Difficult to treat: are there organism-dependent differences and overall risk factors in success rates for two-stage knee revision? Arch Orthop Trauma Surg. 2020;140:1595-602.

33. Kubista B, Hartzler RU, Wood CM, Osmon DR, Hanssen AD, Lewallen DG. Reinfection after two-stage revision for periprosthetic infection of total knee arthroplasty. Int Orthop. 2012;36(1):65-71.

34. Akgun D, Perka C, Trampuz A, Renz N. Outcome of hip and knee periprosthetic joint infections caused by pathogens resistant to biofilm-active antibiotics: results from a prospective cohort study. Arch Orthop Trauma Surg. 2018;138(5):635-42.

35. Zimmerli W, Moser C. Pathogenesis and treatment concepts of orthopaedic biofilm infections. FEMS Immunol Med Microbiol. 2012;65(2):158-68.

36. Parvizi J, Ghanem E, Menashe S, Barrack RL, Bauer TW. Periprosthetic infection: what are the diagnostic challenges? J Bone Joint Surg Am. 2006;88:138-47.

37. Azzam K, McHale K, Austin M, Purtill JJ, Parvizi J. Outcome of a second two-stage reimplantation for periprosthetic knee infection. Clin Orthop Relat Res. 2009;467(7):1706-14.

38. Jamsen E, Huhtala H, Puolakka T, Moilanen T. Risk factors for infection after knee arthroplasty. A register-based analysis of 43,149 cases. J Bone Joint Surg Am. 2009;91(1):38-47.

39. Sabry FY, Buller L, Ahmed S, Klika AK, Barsoum WK. Preoperative prediction of failure following two-stage revision for knee prosthetic joint infections. J Arthroplasty. 2014;29(1):115-21.

40. Fehring KA, Abdel MP, Ollivier M, Mabry TM, Hanssen AD. Repeat Two-Stage Exchange Arthroplasty for Periprosthetic Knee Infection Is Dependent on Host Grade. J Bone Joint Surg Am. 2017;99(1):19-24.

41. Vadiee I, Backstein DJ. The Effectiveness of Repeat Two-Stage Revision for the Treatment of Recalcitrant Total Knee Arthroplasty Infection. J Arthroplasty. 2019;34(2):369-74.

42. Corvec S, Furustrand Tafin U, Betrisey B, Borens O, Trampuz A. Activities of fosfomycin, tigecycline, colistin, and gentamicin against extended-spectrumbeta-lactamase-producing Escherichia coli in a foreign-body infection model. Antimicrob Agents Chemother. 2013;57(3):1421-7.

43. Furustrand Tafin U, Majic I, Zalila Belkhodja C, Betrisey B, Corvec S, Zimmerli W, et al. Gentamicin improves the activities of daptomycin and vancomycin against Enterococcus faecalis in vitro and in an experimental foreign-body infection model. Antimicrob Agents Chemother. 2011;55(10):4821-7.

44. Oliva A, Furustrand Tafin U, Maiolo EM, Jeddari S, Betrisey B, Trampuz A. Activities of fosfomycin and rifampin on planktonic and adherent Enterococcus faecalis strains in an experimental foreign-body infection model. Antimicrob Agents Chemother. 2014;58(3):1284-93.

\section{Figures}




\section{Infected primary TKA}

(142 cases, 136 patients)

\section{Study cohort}

Total two-stage knee

revisions for prosthetic

knee infection

(107 cases, 104 patients)

Figure 1

Summary of infected total knee arthroplasty

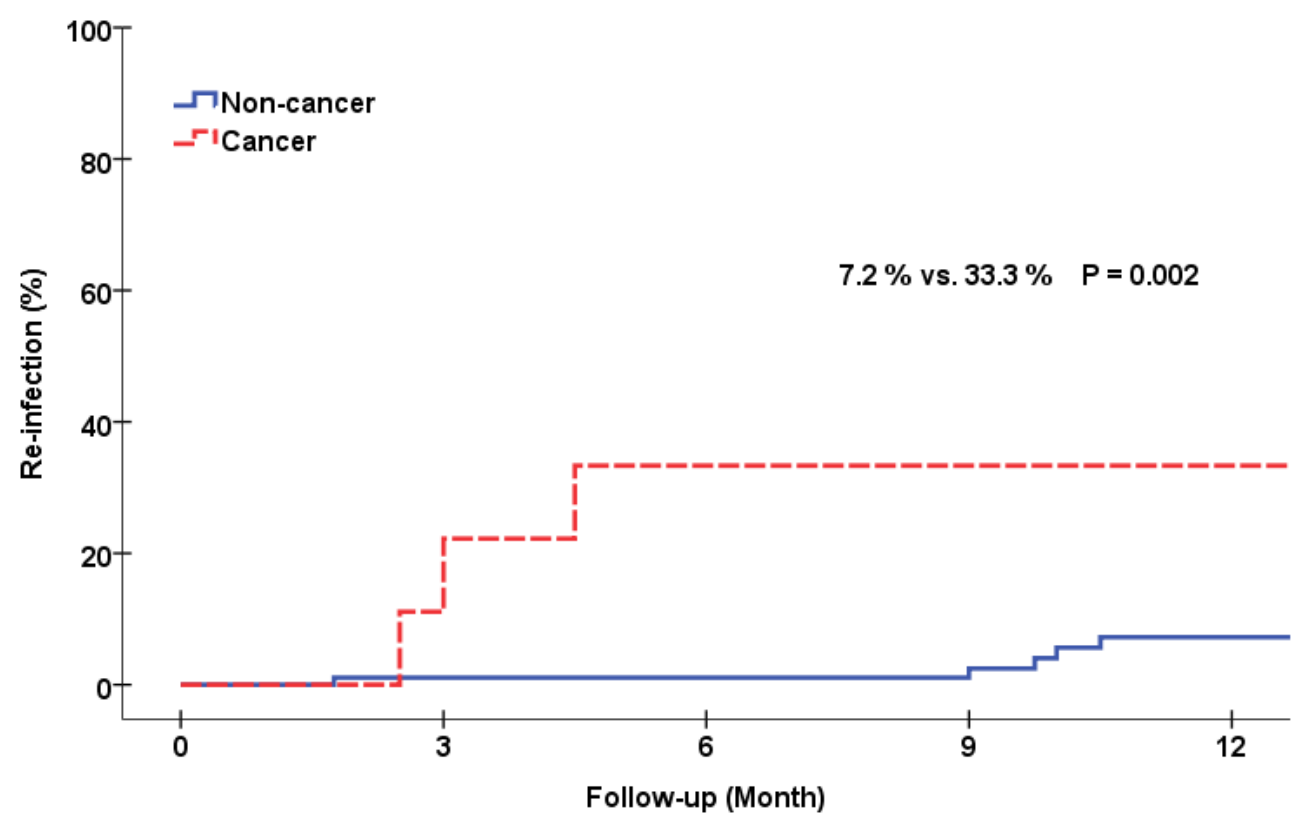

Figure 2

One-year Kaplan-Meier survival analysis of cancer and non-cancer groups after revision total knee arthroplasty 